\title{
Relationship between ecological indicators and teak wood characteristics in Tchorogo plantation (Togo)
}

\author{
Adzo Dzifa KOKUTSE *, Kossi ADJONOU and Kouami KOKOU
}

Laboratoire de Botanique et Ecologie Végétale, Faculté des Sciences, Université de Lomé, BP: 1515, Lomé, Togo, Tel: (+228) 225-50-94, Fax: (+228) 221-85-95.

*Corresponding author, Email: mimidam@hotmail.com

\begin{abstract}
In the Tchorogo teak plantation in the Central Region of Togo $\left(1^{\circ} 00^{\prime} \mathrm{E}, 8^{\circ} 21^{\prime} \mathrm{N}\right)$, a contribution to the sustainable forest management was implemented through the study of the relationship between ecological indicators and anatomical parameters of teak wood. To do this, three phytocoenoses have been described in the forest, using the synusial approach inside the undergrowth plant communities. In each phytocoenose, silvicultural parameters of plantations and anatomical properties of teak wood were studied taking into account the age of the trees. Results showed that teak productivity level, which is linked to the fibre properties of teak wood varied significantly $\left(\mathrm{F}_{749,2}=71.81 ; \mathrm{P}<0.001\right.$ for fibre length; $\mathrm{F}_{749,2}=5.39 ; \mathrm{P}=0.005$ for fibre width; $\mathrm{F}_{749,2}=$ 8.99; $\mathrm{P}<0.001$ for fibre lumen diameter; $\mathrm{F}_{749,2}=8.16 ; \mathrm{P}=0.04$ for fibre wall thickness); they depend on the age of the stands and ecological factors inside phytocoenoses. This research demonstrated that the synusial approach to phytosociology can be used in teak plantation to predict wood quality. As main wood properties depend on wood anatomy, the undergrowth plant communities in teak stand provide precious and useful information about some wood properties (strength properties). One of the conclusion is that Forest Management Units (FMUs) could be implemented in accordance to ecological indicators, trees productivity and wood quality in Togolese teak plantations.
\end{abstract}

() 2009 International Formulae Group. All rights reserved.

Keywords: Teak plantation, Togo, phytocoenose, ecological indicators, teak wood, anatomical properties.

\section{INTRODUCTION}

Teak is one of the most important forest tree species in tropical regions. The valuable qualities of teak wood such as mechanical properties, natural durability, dimensional stability and aesthetic aspects (colour, figure and vein), make it exceptional for furniture, parquet flooring and marine furnishing. Most of these qualities are conferred to the teak wood by anatomical properties such as fibre, vessel element, longitudinal parenchyma and ray parenchyma (Rahman et al., 2003). The proportion of the fibre in teak wood is the highest (about 65\%), compared to the proportion of the vessels and the parenchyma (Bhat et al., 2004). However this proportion could vary among different provenances of teak. Fibre length ranged from $1000 \mu \mathrm{m}$ to $1500 \mu \mathrm{m}$ between juvenile and mature wood (Bhat et al., 2001). Teak wood is well known as a ring porous wood, with distinct growth rings. Earlywood vessels are large, solitary or in radial groups, while latewood vessels are smaller and evenly distributed (Hoadley, 1990; Richter and Dallwitz, 2000). Though faster growth speed increases rings width and modifies the characteristics of the vessels and their distribution in the rings. The presence and the aspect of the ring-porous zone, analogous to earlywood in temperate trees, seem to be altered by growth, itself modified by climate variation. Bhat (2000) found out the loss of the typical ring porosity in trees grown faster, 
and the same occurrence was noticed in plant grown with good water availability during the vegetation period (Priya and Bhat, 1999). Macchioni et al. (2007) had also shown that growth environment has a great impact on the anatomical characteristics of teak wood from West Africa.

Teak was introduced in Togo (WestAfrica) since 1920 (Lamouroux, 1957). Teak plantations are increasing and have been estimated to 14.000 hectares (Tengué, 1995). However, silviculture is not generally guided by sound research results. Little information exits concerning the volume and quality of heartwood in Togolese teak plantation (Kokutse et al., 2004). Other studies had shown the resistance of these plantations to fungi and insect degradations (Kokutse et al., 2005; 2006). Recent study showed lesser genetic diversity in teak populations of Togo (Logossa, 2006).

In Benin Republic, with similar ecological context as Togo, an interesting application in forest management had been derived from the study of the relationship between ecological factors and productivity levels in teak stands (Ganglo and de Foucault, 2006; Noumon et al., 2009). Using synusial approach to phytosociology (Gillet et al., 1991; Gillet, 2000; Noumon et al., 2009), these authors have described undergrowth plant communities (or phytocoenoses) in teak stands and showed the impacts of the ecological variation on teak trees dendrometric parameters within the phytocoenoses. Following the same approach, the purpose of this paper is to present the relationship between ecological factors and anatomical parameters of teak wood from different phytocoenoses identified in Tchorogo teak plantation in the central region of Togo.

\section{MATERIALS AND METHODS Site description}

The study site is Tchorogo teak plantation $\left(1^{\circ} 00^{\prime} \mathrm{E}, 8^{\circ} 21^{\prime} \mathrm{N}\right)$ in the Central Togo, West Africa (Figure 1). The teak stand of Tchorogo is located in the Guinean woody savannah area in Togo. A small enclave of dry semi deciduous natural forests was maintained in this teak plantation (Kokou et al., 2006). The altitude varies between 200 and $400 \mathrm{~m}$
(Aubréville, 1937; Ern, 1979). The climate is tropical with two major seasons per year, one long rainy season from $6-8$ months, followed by a long dry season. Mean annual precipitation is $1300-1600 \mathrm{~mm}$ and temperatures vary from $24-30 \quad{ }^{\circ} \mathrm{C}$ with extreme temperatures reaching $40{ }^{\circ} \mathrm{C}$. Soil type is ferruginous soil with a clay/sandy silt structure (Kokutse et al., 2004). Based on the synusial approach to phytosociology (Gillet et al., 1991; Gillet, 2000), three phytocoenoses were described in Tchorogo forest (Adjonou, 2007) (Figure1). These phytocoenoses are (Table 1):

- Daniellia oliveri arborescent phytocoenose grows on tropical ferruginous soils, hydromorphic of sandy-gravelous texture or stony and marked in some areas by the existence of cuirass. Indeed the hydromorphic soils, presence of stones and cuirass within this phytocoenose, constitute many constraints that prevent the good development of the teak; - Ressantia indica arbustivo-lianescente phytocoenose develops on the cuirass plateaux with a thin layer ferrallitic soils, of sandygravelous texture and with a weak capacity of water retention. The presence of cuirass and gravels, with a relatively high proportion in some areas, constitute the main mechanical constraints of the harmonious development of the teak in this phytocoenose;

- Icacina senegalensis phytocoenose grows in the low hillside, on deep and relatively rich soil. This type of soil is the most suitable for the development of the teak trees in Togo.

\section{Measurement of fibre parameters}

Three teak stands with different age were randomly selected (Tables 1, 2 and 3). From each stand, five teak trees were sampled randomly. About $1 \mathrm{~cm}$ thick cross-sectionnal block of wood were removed from breast height level to study anatomical property. For each tree, one radial position (the outer heartwood) was studied. Anatomical properties studied were fibre length, fibre width, fibre wall thickness and fibre lumen diameter.

Each wood sample was put in a testtube containing a 1/1 mixture of acetic acid and pure hydrogen peroxide solution. The tubes were put in an oven at a temperature of $70{ }^{\circ} \mathrm{C}$ during 24 hours. After staying in 


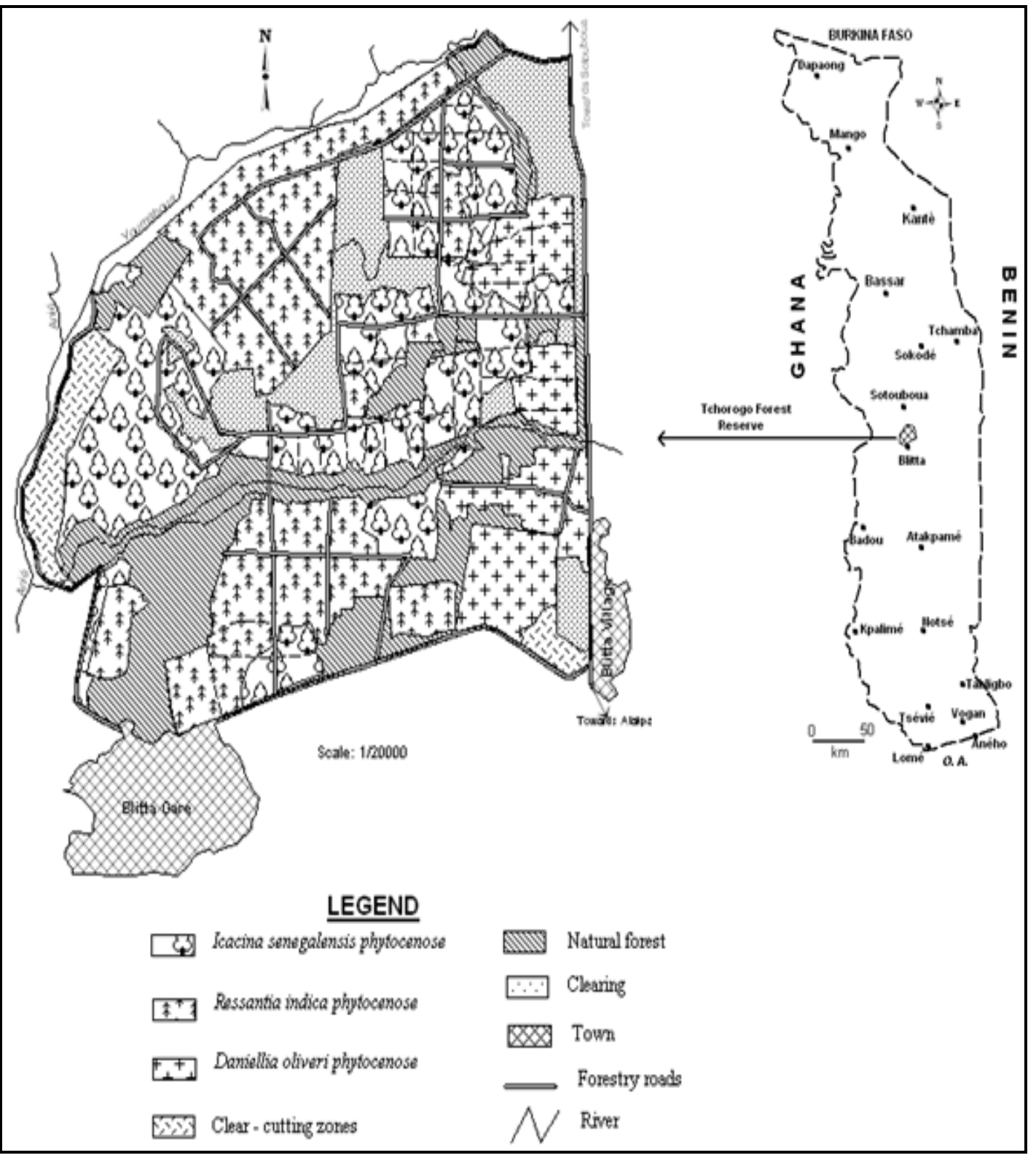

Figure 1: Land use and phytocoenoses in Tchorogo forest reserve.

the oven, wood samples which became white were rinsed with water. Tubes were then strongly shaken in order to dissociate fibres and to isolate them individually. Solution drops of each tube containing fibres were assembled with blade and plates. All fibre parameters were measured using an optical microscope and a graduated micrometer. Fifty individualized fibres were measured for each wood sample. For each test tube, 150 measures were made: 50 for the fibres length,
50 for the fibre width and 50 for the lumen diameter of fibre. The fibre wall thickness was calculated as follows:

Fibre wall thickness $(\mu \mathrm{m})=\mathrm{DR}-\mathrm{DL}$ (where DR $=$ Fibre width $(\mu \mathrm{m})$ and $\mathrm{DL}=$ lumen diameter of the fibre $(\mu \mathrm{m}))$.

An analysis of variance was carried out to determine the differences in fibre parameters within each phytocoenose depending on the age of trees, and between different phytocoenose. Values were 
considered statistically significant if $\mathrm{P}<0.05$. To evaluate the effect of ecological factors on fibre characteristics, the stands of relatively similar age $(27,29,31$ years old) were considered throughout the three phytocoenose. The productivity indexes for each phytocoenose were calculated for a reference age of 25 years, representing the dominant height reached by the plantations at this age (Maître, 1983).

\section{RESULTS}

Variability within phyotocoenose Daniellia oliveri phytocoenose

Fibre length ranged from $1.27 \pm 0.14$ $\mathrm{mm}$ in 53 old teak stands to $1.38 \pm 0.13 \mathrm{~mm}$ in 31 old teak, (Table 2). Significant differences were observed in fibre length inside stand $\left(\mathrm{F}_{699,2}=28.75 ; \mathrm{P}<0.001\right)$. However, no such clear tendencies were observed depending on the stand age. Fibre from 53 old teak stands were the shortest where teak wood from 31 old stands presented the longest fibre. Fibre width ranged from $24.70 \pm 3.53 \mu \mathrm{m}$ in the youngest stand (12 years old) to $25.42 \pm 2.98$ $\mu \mathrm{m}$ in the oldest stand (53 years old). The fibre width differed significantly inside the stands and tended to increase with the age of the tree $\left(\mathrm{F}_{699,2}=3.34 ; \mathrm{P}=0.036\right)$. Fibre wall tickness is about $22.26 \mu \mathrm{m}$ in the 53 years old stand and $21.51 \mu \mathrm{m}$ in the 12 years old stand. Fibre lumen diameter varied from 2.93 to 3.18 $\mu \mathrm{m}$. With regard to age, the fibre wall tickness differed significantly $\left(\mathrm{F}_{699,2}=4.65 ; \mathrm{P}=0.01\right)$ but fibre lumen diameter varied insignificantly.

\section{Ressantia indica phytocoenose}

Fibre length varied from $1.35 \pm 0.18 \mathrm{~mm}$ in the 12 years old stand to about $1.50 \mathrm{~mm}$ in the older stands (Table 3). With regard to age, fibre length differed significantly between the young stand (12 years old) and the others (20 and 29 years old respectively), $\left(\mathrm{F}_{749,2}=62.09\right.$; $\mathrm{P}<0.001)$. However, no significant differences were observed between the stand of 20 years and the stand of 29 years. In the young stand, fibre width mean was about $24.66 \mu \mathrm{m}$, however, the highest value of fibre width $(25.72 \mu \mathrm{m})$ was observed in the old stand $(29$ years old). Fibre width tended to increase significantly with stand age $\left(\mathrm{F}_{749,2}=8.27\right.$; $\mathrm{P}<0.001)$ but no significant differences were observed between the stand of 20 years and that of 29 years. Likewise fibre width, fibre wall tickness increased significantly
$\left(\mathrm{F}_{749,2}=9.85 ; \quad \mathrm{P}<0.001\right)$ but fibre lumen diameters increased insignificantly depending on the age of the stand.

\section{Icacina senegalensis phytocoenose}

Within this phytocoenose, fibre length varied significantly depending on the age of the site $\left(\mathrm{F}_{699.2}=14.04 ; \mathrm{P}<0.001\right)$. The longest fibre were observed in the stand of 24 years old and the shortest fibre were observed in the stand of 21 years old (Table 4). However, no significant differences were found between 24 and 27 years teak stands with regard to fibre length. Fibre width and fibre wall thickness ranged from 25.57 to $26 \mu \mathrm{m}$ and from 22.30 to $22.73 \mu \mathrm{m}$ respectively. With regard to the stands, the fibre width, the fibre wall thickness and the fibre lumen diameter varied insignificantly.

\section{Variability between phytocoenose}

The fibre length differed significantly between phytocoenoses $\quad\left(\mathrm{F}_{749,2}=71.81\right.$; $\mathrm{P}<0.001)$. Teak from Icacina senegalensis phytocoenose, which grows in the deep and relatively rich soil, presented the longest fibre $(1.52 \pm 0.14 \mathrm{~mm})$ while the shortest fibre was obtained in teak from Daniellia oliveri phytocoenose $(1.38 \pm 0.15 \mathrm{~mm})$. Daniellia oliveri phytocoenose grows in a soil which is much poorer. When considering the fibre width, teak from Icacina senegalensis and Ressantia indica phytocoenoses presented significantly the largest fibre (about $26 \mu \mathrm{m}$ ), $\left(\mathrm{F}_{749,2}=5.39 ; \mathrm{P}=0.005\right)$. However teak from Daniellia oliveri phytocoenose presented the lowest value of fibre width (Table 5). Fibre lumen diameter did not differ significantly between teak trees from Icacina senegalensis and Ressantia indica phytocoenoses. However when all phytocoenoses were considered, teak from Daniellia oliveri phytocoenose showed significantly the smallest fibre lumen diameter $\left(\mathrm{F}_{749,2}=8.99 ; \mathrm{P}<0.001\right)$. Fibre wall thickness was also affected by ecological factors. It was observed that teak trees from Icacina senegalensis and Ressantia indica phytocoenoses presented significantly thicker fibre wall than teak from Daniellia oliveri phytocoenose $\quad\left(\mathrm{F}_{749,2}=3.16 ; \quad \mathrm{P}=0.04\right)$. The thickest fibre wall was from Ressantia indica phytocoenose $(22.52 \pm 2.29 \mu \mathrm{m})$.

\section{DISCUSSION}

The results of this study showed that 
Table 1: Tree characteristics.

\begin{tabular}{|c|c|c|c|c|c|c|c|c|c|}
\hline \multirow{2}{*}{$\begin{array}{l}\text { Phytocoenose } \\
\text { characteristics }\end{array}$} & \multicolumn{3}{|c|}{ Daniellia oliveri phytocoenose } & \multicolumn{3}{|c|}{ Ressantia indica phytocoenose } & \multicolumn{3}{|c|}{ Icacina senegalensis phytocoenose } \\
\hline & 12 years & 31 years & 53 years & 12 years & 20 years & 29 years & 21 years & 24 years & 27 years \\
\hline Stand density & 320 & 283 & 272 & 462 & 448 & 352 & 368 & 336 & 317 \\
\hline $\begin{array}{l}\text { Mean stand } \\
\text { DBH }(\mathrm{cm})\end{array}$ & $12.34 \pm 2.05$ & $19.11 \pm 9.30$ & $22.48 \pm 5.67$ & $13.65 \pm 3.68$ & $20.23 \pm 5.30$ & $26.16 \pm 4.67$ & $21.33 \pm 1.88$ & $25.21 \pm 2.23$ & $25.37 \pm 2.03$ \\
\hline Height (m) & $8.84 \pm 0.88$ & $10.24 \pm 0.97$ & $11.32 \pm 1.02$ & $13.56 \pm 0.95$ & $14.61 \pm 1.82$ & $16.21 \pm 1.42$ & $19.88 \pm 0.98$ & $20.62 \pm 1.78$ & $21.75 \pm 1.04$ \\
\hline
\end{tabular}

DBH is the diameter at breast height.

Table 2: Fibre characteristics of teak wood in Daniellia oliveri phytocoenose.

\begin{tabular}{lcccc}
\hline Fibre parameters & \multirow{2}{*}{ Fibre length $(\mathbf{m m})$} & Fibre width $(\boldsymbol{\mu m})$ & Fibre lumen diameter $(\boldsymbol{\mu m})$ & Fibre wall tickness $(\boldsymbol{\mu m})$ \\
\cline { 1 - 3 } Age of teak stand (years) & & $25.42 \pm 2.98$ & $3.16 \pm 0.99$ & $22.26 \pm 2.44$ \\
33 & $1.27 \pm 0.14$ & $24.91 \pm 2.78$ & $2.93 \pm 0.76$ & $21.98 \pm 2.38$ \\
12 & $1.38 \pm 0.138$ & $24.70 \pm 3.53$ & $3.18 \pm 0.99$ & $21.51 \pm 2.99$ \\
\hline
\end{tabular}

Table 3: Fibre characteristics of teak wood in Ressantia indica.

\begin{tabular}{lcccc}
\hline Fibre parameters & \multirow{2}{*}{ Fibre length $(\mathbf{m m})$} & Fibre width $(\boldsymbol{\mu m})$ & Fibre lumen diameter $(\boldsymbol{\mu m})$ & Fibre wall tickness $(\boldsymbol{\mu m})$ \\
\cline { 1 - 3 } Age of teak stand (years) & & & $3.21 \pm 1.07$ & $22.52 \pm 2.29$ \\
\hline 29 & $1.47 \pm 0.11$ & $25.72 \pm 2.96$ & $3.14 \pm 0.96$ & $22.27 \pm 2.58$ \\
20 & $1.48 \pm 0.14$ & $25.41 \pm 3.20$ & $3.06 \pm 0.94$ & $21.59 \pm 2.34$ \\
12 & $1.35 \pm 0.18$ & $24.66 \pm 2.86$ & & \\
\hline
\end{tabular}


Table 4: Fibre characteristics of teak wood in Icacina senegalensis.

\begin{tabular}{lcccc}
\hline Fibre parameters & $\begin{array}{c}\text { Fibre length } \\
\text { Age of teak stand (years) }\end{array}$ & $\begin{array}{c}\text { Fibre width } \\
(\boldsymbol{\mu m})\end{array}$ & $\begin{array}{c}\text { Fibre lumen } \\
\text { diameter }(\boldsymbol{\mu m})\end{array}$ & $\begin{array}{c}\text { Fibre wall } \\
\text { thickness }(\boldsymbol{\mu m})\end{array}$ \\
\hline 27 & $1.52 \pm 0.14$ & $25.57 \pm 3.04$ & $3.26 \pm 0.95$ & $22.30 \pm 2.54$ \\
24 & $1.55 \pm 0.13$ & $26.01 \pm 3.82$ & $3.27 \pm 1.15$ & $22.73 \pm 2.97$ \\
21 & $1.47 \pm 0.16$ & $25.77 \pm 2.87$ & $3.13 \pm 0.85$ & $22.64 \pm 2.30$ \\
\hline
\end{tabular}

Table 5: Fibre characteristics in teak wood depending on phytocoenose.

\begin{tabular}{lccc}
\hline Fibre characteristics & $\begin{array}{c}\text { Daniellia oliveri } \\
\text { (31 years) }\end{array}$ & $\begin{array}{c}\text { Ressantia indica } \\
(\mathbf{2 9} \text { years) }\end{array}$ & $\begin{array}{c}\text { Icacina senegalensis } \\
\text { (27 years) }\end{array}$ \\
\hline Fibre length $(\mathrm{mm})$ & $1.38 \pm 0.15$ & $1.47 \pm 0.11$ & $1.52 \pm 0.14$ \\
Fibre width $(\mu \mathrm{m})$ & $24.91 \pm 2.78$ & $25.72 \pm 2.96$ & $25.57 \pm 3.04$ \\
Fibre lumen diameter $(\mu \mathrm{m})$ & $2.93 \pm 0.75$ & $3.21 \pm 1.07$ & $3.26 \pm 0.95$ \\
Fibre wall tickness $(\mu \mathrm{m})$ & $21.98 \pm 2.38$ & $22.52 \pm 2.29$ & $22.30 \pm 2.54$ \\
Site productivity $(\mathrm{m})$ & $16.43 \pm 1.22$ & $22.82 \pm 1.87$ & $27.91 \pm 1.30$ \\
\hline
\end{tabular}

fibre properties of teak wood varied widely, depending on the age of the stands and the phytocoenose characteristics. Analysis of fibre characteristics showed that teak wood from Togolese plantation presents similar property to those from Asia. In Tchorogo plantation, teak wood fibre length was about $1.45 \mathrm{~mm}$ in young stands. When comparing this result to that in teak plantation from Kerala, India, it was found that in juvenile teak wood, fibre length was about $1.40 \mathrm{~mm}$ (Bhat et al., 2004). In young teak stands, fibre length increased with the age of the tree, due to the formation of juvenile wood. However, no significant differences were observed between the stand of 20 years and the stand of 29 years in Ressantia indica phytocoenose. Likewise in Icacina senegalensis phytocoenose, teak stands of 24 and 27 years did not show any significant differences in fibre length. Bhat et al. (2004) also found that in teak wood from India, fibre length increased in the young tree and maturation reached around $15-25$ years depending on the locality. After this age, fibre length did not vary significantly. Then, it could be considered that in Togolese teak plantation, the critical age of demarcation between juvenile and mature wood was somewhere between 20-25 years. Juvenile wood is formed from a juvenile cambium during the early years of physiological activity (Zobel and van Buijtenen, 1989; Bhat et al., 2001; Medzegue et al., 2007). Mature wood is then produced and usually has thinner annual growth rings, a higher longitudinal modulus of elasticity $\left(E_{L}\right)$, higher density and greater dimensional stability due to changes in xylem structure. Shorter fibre observed in old stand (53 years old) from Daniellia oliveri phytocoenose could be attributed to the lack of sylvicultural practices. The teak plantations in Togo dates back to the end of World War I, and old plantations have apparently never, or rarely been thinned. Therefore, the number of stems per hectare is too high for optimum growth (Delvaux, 1973).

Inside phytocoenose, fibre lumen diameter was not significantly affected by the age of teak tree. It demonstrates the stability of fibre lumen when the environmental conditions present relatively a homogeneity, resulting from the combined action of the soil and the topography. Except Icacina senegalensis phytocoenose, the fibre width differed significantly inside the stands and tended to increase with the age. This can be attributed to a higher degree of lignification with the age, showed by the fibre wall thickness variation. The role of cell wall thickness as one of the structural determinants of bending strength of teak wood has been demonstrated (Bhat et al., 2000). Therefore, wood strength properties would increase with the age of the tree.

When considering the three phytocoenoses at the same age, all fibre 
characteristics differed significantly depending on ecological and edaphic factors within phytocoenoses. Teak from Icacina senegalensis phytocoenose, which presents the highest index of productivity showed the longest fibre. However the shortest fibre was obtained from Daniellia oliveri phytocoenose, which presents the lowest index of productivity of the teak tree. The primary function of the longitudinal fibre is to give mechanical support to the tree, so their length influences the strength properties of the wood material (Polato et al., 2005). Therefore, in Tchorogo forest, teak from Icacina senegalensis phytocoenose, which presents the longest fibre could present better strength properties.

Even though fibre lumen diameter was not affected by the age of the tree inside phytocoenose, a significant difference was observed between phytocoenoses depending on ecological factors. The largest fibre and the highest mean lumen diameters were found in teak from Icacina senegalensis and Ressantia indica phytocoenoses. Teak from Daniellia oliveri phytocoenose showed once again the lowest value for fibre width and fibre lumen diameter. Therefore, these variations in fibre characteristics may be attributed to changes in environmental factors in Daniellia oliveri phytocoenose. In teak wood (Priya and Bhat, 1998) or in other species, several authors have demonstrated the influences of ecological or environmental factors on wood anatomy and on fibre characteristics (Noshiro and Suzuki, 1995; Noshiro and Baas, 2000; Liu and Noshiro, 2003; Lens, 2004; Honjo et al., 2005). In this study, fibre wall thickness was also affected by ecological factors. It was observed that teak trees from phytocoenoses which are grown on relatively rich soil presented significantly thicker fibre wall than teak from poor soil. Teak from Ressantia indica phytocoenose which present the intermediary index of productivity, showed better fibre characteristics than teak wood from Daniellia oliveri phytocoenose which is grown in the poorer soil. The latest phytocoenose is characterized by hydromorphic soil. This type of soil results in poor root growth, with consequences for tree health and vigour (Lamouroux, 1957; Kokutse et al., 2004). The presence of stones and cuirass inside this phytocoenose, also constitute constraints which are not suitable for the good development of the teak trees. Therefore, teak wood from this phytocoenose may be affected by these edaphic factors, resulting in poorer characteristics observed in the wood. These changes in wood fibre indicate that teak wood xylem is widely influenced by environmental factors.

\section{Conclusion}

This study demonstrated the possibility to predict wood quality, using synusial approach to phytosociology in the undergrowth plant communities in teak plantation. As main wood properties depend on wood anatomy, this approach provides precious and useful information about some wood properties, e.g. strength properties. Icacina senegalensis phytocoenose presented the highest index of productivity and the best strength properties. Ressantia indica phytocoenose which presents the intermediary index of productivity, also showed better fibre characteristics while teak wood from Daniellia oliveri phytocoenose which grows in the poorer soil presented poorer characteristics in the wood. To profit more in teak plantations in Togo, the forestry department must rely on scientist research like the current study in order to implement real Forest Management Units (FMUs) in accordance to ecological homogeneity, trees productivity and wood quality. Another application is that, it is possible to endow these FMUs with management plan and sustainable management orientations. For the choice of relevant FMU based on the findings of this survey, and concerning the technological and aesthetic properties of the wood, the silviculturist could make a compromise between the quality of the wood and the site productivity. In the Tchorogo forest for example, the most productive phytocoenose produces wood with the best fibre characteristics while the least productive phytocoenose produces wood with poor fibre characteristics. So the forest manager could potentially choose the trees by taking into account the expected quality of the final product.

\section{ACKNOWLEDGEMENTS}

Funding was provided by the International Foundation for Science (IFS), Sweden. Thanks are due to Prof. J. C. Ganglo 
(Faculté des Sciences Agronomiques, Cotonou, Benin) for help with phytocoenose analysis.

\section{REFERENCES}

Aubréville A. 1937. Les forêts du Dahomey et du Togo. Bulletin du Comité d'études historiques, 29: 1-113.

Adjonou K. 2007. Influence des facteurs écologiques sur les propriétés biophysiques $\mathrm{du}$ bois de teck en plantation au Togo. M.Sc II thesis, University of Lomé, 64.

Bhat KM. 2000. Timber quality of teak from managed tropical plantations with special reference to Indian plantations. Bois For. Trop., 283: 6-16.

Bhat KM, Priya PB, Mathew A. 2000. Wood biomechanics of fast grown juvenile teak (Tectona grandis L. f.). In Plant Biomechanics, Spatz HC, Speck T (eds). Thieme Verlag: Stuttgart; 397-402.

Bhat KM, Priya PB, Rugmini P. 2001. Characterisation of juvenile wood in teak. Wood Sci. Tech., 34: 517-532.

Bhat KM, Priya PB. 2004. Influence of provenance variation on wood properties of teak from the western ghat region in India. IAWA J., 25(3): 273-282.

Delvaux J. 1973. Production et traitement des teckeraies togolaises. Rapport de l'organisation des Nations Unies pour l'alimentation et l'agriculture.

Ern H. 1979. Die vegetation Togos. Gliederrung. Gefährdung. Willdenowia., 9: 295-312.

Ganglo JC, de Foucault B. 2006. Plant communities, forest site identification and classification in Toffo reserve, SouthBenin. Bois For. Trop., 288(2): 25-38.

Gillet F, de Foucault B, Julve P. 1991. La phytosociologie synusiale intégrée: objets et concepts. Candollea, 46(2): 315-340.

Gillet F. 2000. La phytosociologie synusiale intégrée. Guide méthodologique (4 ème édn revue et corrigée). Université de Neuchâtel. Institut de Botanique. Laboratoire d'écologie végétale et de phytosociologie.

Hoadley RB. 1990. Identifying Wood. Taunton Press: Newtown, CT.

Honjo K, Furukawa T, Sahri MH. 2005. Radial variation of fiber length increment in Acacia mangium. IAWA J., 26(3): 339352.

Kokutse AD, Baillères H, Stokes A, Kokou K. 2004. Proportion and quality of heartwood in Togolese teak (Tectona grandis L. f.). For. Ecol. Manag., 189: 37-48.

Kokutse AD, Stokes A, Baillères H, Baudasse C, Kokou K. 2005. Heartwood and natural decay resistance in plantation grown teak (Tectona grandis L. f.) from Togo, West Africa. In Quality Timber Products of Teak from Sustainable Forest Management, Bhat KM, Nair KKN, Bhat KV, Muralidharan EM, Sharma JK (eds). Peechi. Kerala Forest Research Institute: India; 297-302.

Kokutse AD, Stokes A, Baillères H, Kokou K, Baudassé C. 2006. Decay resistance of Togolese teak (Tectona grandis L. f.) heartwood and relationship with colour. Trees-Struct. Func., 20: 219-223.

Lamouroux M. 1957. Les Sols de Teckeraies du Togo. Doc ORSTOM: France.

Lens F, James LL, Erik S, Steven J. 2004. Ecological trends in the wood anatomy of Vaccinioideae (Ericaceae s.). Flora., 199: 309-319.

Liu J, Noshiro S. 2003. Lack of latitudinal trends in wood anatomy of Dodonaea viscosa (Sapindaceae) a species with a worldwide distribution. Am. J. Bot., 90: 532-539.

Logossa ZT. 2006. Caractérisation génétique des Tecks (Tectona grandis L. f.) provenant de plantations du Togo. Master II thesis, Université de Bordeaux 1, 29.

Macchioni N, Nocetti M, Rozenberg P. 2007. Early detection of surface quality of Teak (Tectona grandis L. f.) through X-Ray microdensitometry. Test on west African plantations. International Scientific Conference on Hardwood Processing. Quebec City: Canada; 311-315.

Maître HF. 1983. Table de production provisoire du teck (Tectona grandis) en Côte d'Ivoire. Doc. CTFT.

Medzegue M, Grelier S, M'Batchi B, Nziengui M, Stokes A. 2007. Radial growth and characterization of juvenile and adult wood in plantation grown Okoumé (Aucoumea klaineana Pierre) from Gabon. Ann. For. Sci., 64: 815-824. 
Noshiro S, Suzuki M. 1995. Ecological wood anatomy of Nepalese Rhododendron (Ericaceae). 2. Intraspecific variation. $J$. Plant Res., 108: 217-233.

Noshiro S, Baas P. 2000. Systematic wood anatomy of Cornaceae and allies. IAWA J., 19: 43-97.

Noumon JC, Ganglo JC, Azontondé A, de Foucault B, Adjakidjè V. 2009. Ecological and silvicultural indicatory value of plant-communities of Koto forest reserve (Centre-Benin). Int. J. Biol. Chem. Sci., 3: 367-377.

Polato R, Laming PB, Sierra-Alvarez R. 2005. Assessment of some wood characteristics of teak of Brazilian origin. In Quality Timber Products of Teak from Sustainable Forest Management, Bhat KM, Nair KKN, Bhat KV, Muralidharan EM, Sharma JK (eds). Peechi. Kerala Forest Research Institute: India; 257-265.

Priya PB, Bhat KM. 1998. False ring formation in teak (Tectona grandis L. f.) and the influence of environmental factors. For. Ecol. Manag., 108: 215-222.

Rahman MM, Fujiwara S, Hirakawa Y, Kanagawa Y. 2005. Variation in volume and dimensions of ray of teak grown in Bangladesh. In Quality Timber Products of Teak from Sustainable Forest Management, Bhat KM, Nair KKN, Bhat KV, Muralidharan EM, Sharma JK (eds). Peechi. Kerala Forest Research Institute: India ; 307-310.

Richter HG, Dallwitz MJ. 2000. Commercial timbers: descriptions, illustrations, identification, and information retrieval. In English, French, German and Spanish. Version: 4th 2000. http://biodiversity.uno.edu/delta/.

Souvannavong O. 1986. Les teckeraies togolaises. Aménagement des parcelles à objectif bois d'œuvre. Rapport ODEF: Togo.

Tengué KM. 1995. Examen mi-parcours de 1995, Rapport interne de l'Office de développement et d'exploitation des forêts du Togo «l'objectif an 2000 de l'OIBT. Lomé Togo.

Zobel JB, van Buijtenen JP. 1989. Wood Variation. Its Causes and Control. Springer-Verlag, Series in Wood Science: Berlin. 